 \\ Jurnal Terapan Manajemen dan Bisnis is licensed under \\ A Creative Commons Attribution-NonCommercial 4.0 International License.
}

\title{
Influence of Motivation and Job Training The Performance of Employees PT. RB Sukasada Palembang.
}

\author{
Ika Rakhmalina'),Emelda ${ }^{2), H a r a p i n ~ H a f i d}{ }^{3),}$ Periansya ${ }^{3)}$ \\ 1) STIE Rahmaniyah Sekayu, Indonesia \\ Email: ika.rakhmalina1983@gmail.com \\ 2) STIE Rahmaniyah Sekayu, Indonesia \\ Email: imeldaoedrman@yahoo.com \\ 3) Harapin Hafid, Halu Oleo University \\ email: harapinhafid14@gmail.com \\ 4) Polytechnic of Sriwijaya, Indonesia \\ email: periansyazz@gmail.com
}

\begin{abstract}
The purpose of this study was to determine the effect of motivation and job training to employees performance of PT. RB Sukasada. This research is causality. The population in this study is the overall employees of PT. RB Sukasada Jl. Kebumen Land No. 901-902, 17 Ilir, Ilir Tim. I, Palembang, South Sumatra 30122, amounting to 39 employees, with census sampling.Data collection techniques used in this study was a questionnaire with the answer given a score based on a scale interval of 1-5 with the Likert method. With multiple linear regress analysis tools. The next test of the hypothesis that $\mathrm{f}$ test and t-test to determine of independent variables on the dependent variable, and making inferences. Data analysis techniques in this study assisted by the Statistical program for special science (SPSS) The results of research by $\mathrm{F}$ test resulted in no significant effect Motivation and Job Training together with the Employee Performance at PT. RB Sukasada with a coefficient of determination ( $R$ Square) of $34.9 \%$. While based on the t-test a significant difference between motivation and job training partially on performance. With the results of multiple regression $57.0 \%$ effect of motivation on the performance and $47.6 \%$ influence on the performance of job training. Conclusion motivation and job training are still low in achieving performance.
\end{abstract}

Keywords: motivation, job training, performance.

\section{Introduction}

Employees of an agency basically the only major source of an organization that can not be replaced by other resources, because no matter how good an organization, complete amenities, and facilities will not be helpful in the absence of an employee who set up, use and maintains. The success of the institution in achieving its objectives is one reflection of an 
effective organization. Employees of banks as providers of financial services are expected to always be ready to perform the task well.

Employees are required to always work with high performance. Employees must be motivated, so as to provide services to customers not impressed slow, lazy and reluctantly. The motivation for employees required to improve service to its customers. Employees in addition to having a high work motivation demanded to always improve the quality of service because it is very necessary training. The training was conducted by the company, in order to balance the demands and technological advances. Job training is one variable that is important in the implementation of tasks. So employees can provide good service, the employee must have a high motivation. In connection with this motivation, Wibowo (2016) argues that: "The impetus to a process of human behaviour on the achievement of goals."

The motivation and morale and job training are indispensable employees in performing tasks, thus if an employee is able to provide high service, the customer will be satisfied, otherwise if given the motivation is low, then the customers who need the service will be dissatisfied. Under these conditions, it is understood that the service can be affected by a given level of motivation, while the training of employees can affect the performance of the employees themselves.

PT. Rural Banks (BPR) Sukasada is one example of a government agency must provide services to clients who require administrative documents, letters and so forth, PT. RB Sukasada as private institutions in charge of providing public services finance always required to work optimally.Pada fact that not all employees of PT. BPR Sukasada able to provide a good service, so does employee morale, not every employee has a high morale, it will certainly affect the performance of employees in the services provided by employees of PT. RB Sukasada. Results of pre-survey showed that there are some problems faced by the employees of PT. BPR Sukasada in providing services to customers, such as: frequent shortage of availability of forms / form administration request of customers, the lack of operating funds, so that employees are not proactive in providing services to customers, the lack of facilities to its customers, the lack of means of transport, making it difficult for employees of sub-districts in the running field assignment.

Some of these problems, of course, will affect employee motivation PT. RB Sukasada and services provided so that it will cause a feeling of dissatisfaction among customers served so that researchers interested in studying this problem. To be able to carry out the task, especially with regard to increasing competition in the business requires companies to have a fast response and flexible to any opportunities, threats from the outside, the demands of customers, the steps of competitors and changes in regulations between fellow RB or by institutions other similar, for example, commercial banks, cooperatives and pawning, which would affect the ability of rural banks to be able to adapt, especially to provide services in payment traffic and other financial services in order to stay alive and developing States; then the performance of the employees plays a very important and decisive. Because corporate objectives can be achieved somewhat depending on the employee who is the controller of all the activities of the company.

In running the company PT. RB Sukasada to employ as many as 39 people. With the largest number are those who have experience of 0-3 years that as many as 28 people or 71.8 percent. And even those who are clustered in the working age 0-3 years are those who occupy important positions. Judging from the conditions related to their educational background, turned out of 39 employees each just 5 and 9 people were educated S1 and S0 and the remaining 25 people (64.1 percent) were those who had a high school. This certainly sees 
companies need to hire people who are experienced, with an adequate educational background so that the target company can achieve. Based on this phenomenon, this study to know how Influence Motivation and Training the Employee Performance PT. RB Sukasada Palembang ".

\section{Methods}

This study uses conclusive studies where the study was designed to assist in the decision making, evaluating and selecting the best alternative in solving a problem. This type of research is conclusive that will be used is a type of causality research. Causality research is research used to find an explanation in the form of causal relationships(causeeffect) of several variables or several strategies developed in management. The variables used in this study consisted of two independent variables(independent variable)and one dependent variable(dependent variable), where the independent variables consisted of motivation (X1) and vocational training $(\mathrm{X} 2)$, while the dependent variable is employee performance $(\mathrm{Y})$.

The population in this study were all employees of PT. RB Sukasada Palembang as many as 39 people. Sampling technique used in this research is a census. Thus, the number of samples in this study were a total of 39 samples.

Data collection techniques used in this study was a questionnaire relating to indicators used. The analytical method used by the author in this study is a quantitative analysis. A method of analysis using the data in the form of numbers or qualitative data were analyzed quantitatively. Data then answers were scored based on a scale interval method Likert scale 1-5. To answer support questions or statements highest score and for answers that do not support questions or statements were given the lowest score.

The analysis technique used to determine the effect of motivation and job training to performance is multiple linear regression analysis. The next test of the hypothesis that $\mathrm{f}$ test and t-test to determine of independent variables on the dependent variable, and making inferences. Data analysis techniques in this study assisted by the Statistical program for special science (SPSS 17.0 forWindows.

\section{RESULTS}

Effect of motivational factors and factors of job training to employees performance of PT. BPR Sukasada Palembang analyzed using statistical test test with SPSS17.0 forWindows.based on calculations using SPSS, obtained by multiple regression test results, which are as follows:

Table IV.1

regression testing results cuoblcioute

\begin{tabular}{|c|c|c|c|c|c|c|}
\hline \multirow[b]{2}{*}{1} & \multirow[b]{2}{*}{ (COU2fSUf) } & \multicolumn{2}{|c|}{ กuaเguqgเq!seq } & \multirow{2}{*}{ 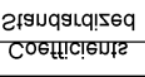 } & \multirow[b]{2}{*}{$3^{3} \pm 15$} & \multirow[b]{2}{*}{ olt } \\
\hline & & 2.3502 & 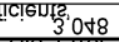 & & & \\
\hline WWOपण & WOf!^S?! & 施o & 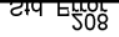 & '505 & $t^{\prime \prime 2} 525$ & 2000 \\
\hline & $\mathrm{D} ! \mathrm{K}|\mathrm{S}|$ & ine & 's0a & .478 & 3'Jaد & '00s \\
\hline
\end{tabular}

DEbeUqGUғ $\wedge$ su!gp|G: K!UGL)

Source: Data Processing 
based on Table IV.1, obtained a constant value (constant) of 2.354; regression coefficient The motivation variable $\left(\mathrm{X}_{1)}\right.$ at 0.570 ; and variable Job Training $\left(\mathrm{X}_{2}\right)$ at 0.476 ; so that it can be established a multiple regression model equation is as follows:

$$
\begin{aligned}
& Y=a+b_{1} . X_{1}+b_{2} . X_{2}+e \\
& Y=2.354+0,570 . X_{1}+0,476 . X_{2}
\end{aligned}
$$

Based on a multiple regression model equations above, it can be interpreted in a constant value (a ) Amounted to 2,354; meaning that if there are no changes to the motivation variable $\left(\mathrm{X}_{1)}\right.$, and the Job Training $\left(\mathrm{X}_{2}\right)$ or equal to $0\left(\mathrm{X}_{1}\right.$ and $\left.\mathrm{X}_{2}=0\right)$, then the Employee Performance $(\mathrm{Y})$ PT.BPR Sukasada amounted to 2,354. While the influence of independent variables on the dependent variable can be seen in the following explanation:

a) Effect of Motivation ( $\mathrm{X}_{1}$ )to the Employee Performance (Y)

motivation variable regression coefficient value $\left(\mathrm{X}_{1)}\right.$ is equal to 0.570 ; means contributions Motivation ( $\mathrm{X}_{1}$ )to the Employee Performance (Y) PT. RB Sukasada amounted to $0.570(57.0 \%)$; so that if increased employee motivation, it will be able to improve the performance of employees at PT. RB Sukasada Palembang. Conversely, if motivation decreases, then it can degrade the performance of employees of PT. RB Sukasada Palembang.

\section{b) Effect of Job Training $\left(\mathrm{X}_{2}\right.$ )the Employee Performance $(\mathrm{Y})$}

The coefficient of regression Training $\left(\mathrm{X}_{2}\right)$ is approximately $0.476(47.6 \%)$; means that the contribution of education and training to employees performance at PT. RB Sukasada was $47.6 \%$; so that when the job training increased by $100 \%$, it will be able to improve the performance of employees at PT. RB Sukasada $47.6 \%$. Vice versa, if the job training has decreased, it can degrade the performance of employees at PT. RB Sukasada Palembang.

Seen determinant coefficient value of $R S q u a r e\left(\mathrm{R}^{2}\right)$. If the value of $R$ Square equal to 0 , then there is the slightest impact that the independent variable on the dependent variable. This analysis is used to determine the effect of independent variables, namely motivation $\left(\mathrm{X}_{1}\right)$ and Job Training $\left(\mathrm{X}_{2}\right.$ )jointly to the dependent variable, namely the Employee Performance (Y), as follows:

Table IV.2

\section{K Test Results Determinants Coefisien}

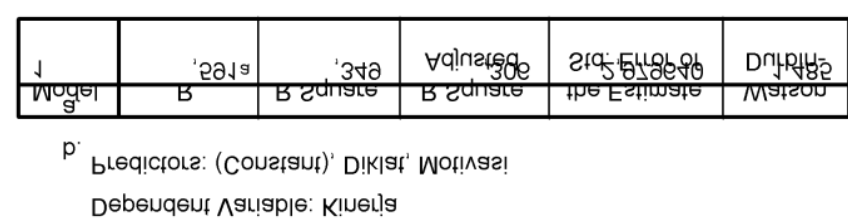

source: Results of Data Processing

Based on Table IV.2., it appears that the value of $R$ Square amounted to 0,349 (34.9\%); The figures mean that the performance of employees at PT. RB Sukasada, can be explained by motivation( $\left.\mathrm{x}_{1}\right)$ and Job Training $\left(\mathrm{X}_{2}\right)$ of $34.9 \%$; while the rest of $65.1 \%$ is explained by other factors not included in this study, such as competencies, job descriptions, job satisfaction, loyalty, organizational climate, working environment, workload, delegating authority, morale, and there are many factors more. 


\section{DISCUSSION}

1. Discussion on the Influence of Motivation and Job Training Collaborative against Employee Performance PT. RB Sukasada

Based on the calculation of the coefficient of determination ( $R$ Square) figures obtained 0,349 (34.9\%); which illustrates that the performance of employees at PT. Sukasada BPR can be explained by the motivation and job training amounted to $34.9 \%$; while the remaining $65.1 \%$ is explained by other factors that are not included in this study. This means that there are many other factors that affect performance, such as competencies, job descriptions, job satisfaction, loyalty, organizational climate, working environment, workload, delegating authority, morale, and many other factors. So if there are other researchers who want to conduct research on objects and similar fields, should include other factors such as those mentioned above.

Furthermore, from the results of hypothesis testing $\mathrm{F}$ (test together), the result that there is a significant effect Motivation and Job Training together with the Employee Performance at PT. RBSukasada.Based on the above test results (test the coefficient of determination and hypothesis test F), can be explained that the variables used in this study are quite able to explain the Employee Performance at PT. RB Sukasada.

The existence of significant influence between motivation and Vocational Training together with the Employee Performance on PT.BPR Sukasada illustrates that the employee's performance is quite good, which is caused because of most of the employees of PT. RB Sukasada believes that the guidelines must be understood in order to support the achievement of maximum work, the employee believes that the level of their loyalty to the job is needed, employees are also aware that creativity in work as well they should have, and they should understand that should generate jobs by level high accuracy.

2. Discussion on the Influence of Motivation on Employee Performance PT. RB Sukasada

Based on calculations using multiple linear regression showed that the motivational effect of $57.0 \%$ on the performance of employees at PT. RB Sukasada, and from the calculation of the $t$ hypothesis testing, explaining that there was a significant effect of motivation partially on the performance of employees at PT. RB Sukasada.

The results of this study explain that the motivation to give a significant role in improving the performance of employees at PT. RB Sukasada. The magnitude of the effect of motivation on employee performance at PT. Sukasada BPR is understandable, given that the motivation is simply a derivative of job satisfaction, meaning employees will be motivated to do the job if they are satisfied in their work, otherwise an employee is not motivated well if the work satisfaction is also low. In many studies explain that the motivation has a direct influence on employee performance. Because if an employee has a high motivation in the work, then it is an indication that either the employee's performance. Conversely, if the employee is not motivated in carrying out its duties, it reflects that the employee's performance is not good.

If the employee motivation is good, it can be ascertained that PT. Sukasada BPR can increase productivity, otherwise, if the employee motivation is bad, then the PT. RB Sukasada will experience many problems. Increased motivation employees, can ultimately improve performance, employee's the so that the estuary is the quality of work, increasing the efficiency and effectiveness of work, improving the quality of employees, as well as the emergence of workplace culture in a creative, productive, professional, responsible and increased competitiveness among employees, groups, institutions or 
agencies/departments, and ultimately to improve the performance of employees in the work.

\section{Discussion on the Influence of Training on Employee Performance PT. RB Sukasada}

Based on the calculation of multiple linear regression showed that the effect of the partial Training on the performance of employees at PT. RB Sukasada was $47.6 \%$. This illustrates that the contribution of job training to employees performance of PT. RB Sukasada was $47.6 \%$. In addition, from the results of hypothesis testing $t$, the result that there is a significant effect partially on the Job Training Employee Performance at PT. RB Sukasada.

Hasilpenelitian illustrates that job training enough to contribute to the improved performance of employees at PT. RB Sukasada. But from the early observations conducted by researchers get an idea that employees at PT. RB Sukasada, still lacking in job training program. This should really be a concern for the management of PT. This Sukasada BPR. We recommend that management should give as many opportunities to employees to participate in education and training (training), good training which is held by PT. RB Sukasada itself, as well as training conducted by other agencies, which has to do with the banking BPR.

Because by following a lot of training, workers will be able to master the field of work that they are responsible, so it will bring efficiency and effectiveness in the implementation of the tasks, which in turn can improve their performance. In addition, following a lot of training, is expected to produce high-quality employees, and is able to provide the best results in achieving the goals of PT. RB Sukasada. Employees are expected to have sufficient competence in the work, but it is expected the employees to master or understand the development of globalization, especially in banking, understanding of banking issues, so that they can transfer to their customers.

In addition, the program Training/Vocational Training has been followed by the employees, still less in accordance with the needs of the job, so it is natural if there are employees who consider training material does not fit the needs of work and training results also cannot be applied in the work. This certainly must seek special attention to the management of PT. BPR Sukasada, that if you want to organize a program of Training, should be tailored to the needs of the job, and if you want to follow privy employees into a training should also be tailored to the needs job, this is done in order not to training which followed became redundant only, and impressed only waste of cost alone.

Therefore, Training and Education/Training to be performed or to be followed should be tailored to the needs of the job, in addition to the training program should be a continuous process, because of the emergence of the conditions of both the development of the banking world, issues of banking, technological developments, and other etc., can be beneficial for the employees in the work, which in turn can improve the performance of employees in the work.

\section{CONCLUSION}

Based on the results of research by the author, then a number of conclusions, as follows:

1. There was a significant effect of motivation and job training together on the performance of employees at PT. RB Sukasada. 
2. There was a significant effect of motivation and job training partially on the performance of employees at PT. RB Sukasada.

3. The most dominant variable influence on the performance of employees at PT. RB Sukasada is motivation variable.

\section{REFERENCES}

AA Anwar Prabu Mangkunegara. (2015). Human Resource Management Company, Publishers Bandung: Teen Rosdakar

Ade Imas (2012). Effect of Motivation and Vocational Training on Employee Performance At Bank BRI Syariah Branch Office Cirebon.

Buchari Zainun. (2011). Management and Motivasi.Jakarta: Literacy Centers

Dessler, Gary. (2010). Human Resource Management. Tenth Edition, Volume One. Jakarta: Index.

Edy Sutrisno (2009). Human Resource Management. First Edition Jakarta: Kencana Prenadamedia Group

Erni Maria Simatupang, (2011) Effect of Job Training and Motivation onPerformance EmployeeAt PT.Perkebunan Nusantara III (Persero) Medan, Thesis, University of North Sumatra, Medan.

Hasibuan, H. Malay, SP, (2011), Human Resource Management, revised edition, printing, third Publisher: BumiAksara, Jakarta

Patricia M. Sahangggamu, Silvya Mandey L. (2014). Effect of Job Training, Motivation, and WorkDiscipline Against Employee Performance at Pt.Fund Rural

RivalBank,Veitzhal. (2009). Islamic Human Capital. Book 1. Jakarta: RajaGrafindo Persada

Rizka Forivera (2013). Effect of Training and Work Motivation on Employee Performance PT. Bumi Minerals Tbk Resourches Kingdom. Emba Journal Vol.2 \# 4 December 2014, ISSN 2303-1174

Robbinss Stephen P. (2006). OrganizationalBehavior (Translation) Volume

1,EdisiKedelapan.Jakarta:

PT. Bhuana IlmuPopuler.

Siagian, Sondra. (2004). Motivation Theory and Its Application. Jakarta: Rineka Copyright Simamora, Henry. (2006). Human Resource Management, 2nd Edition, STIE YKPN. Yogyakarta

Dewi Sri Kurniawati Padma, Titi Laras (2014). Effect of Training, Motivation Work and Work Environment on Employee Performance Student Cooperative (Kopma) In Sleman.Jurnal District Business and Economics Vol. 5, No. 1, June 2014, 48-72

Sugiyono. (2013). Business Research Methods. Bandung: Alfabeta.

Syahyuti. (2010). Definition, Variables, Indicators and Measurement in Social Sciences [on line].

Therehttp://syahyutivariabel.blogspot.com.

Wibowo (2014). Work management. Fourth Edition. Jakarta: Rajawali Pers.

Zainal, Veithzal Rivai, et al. (2014). Human Resource Management For Companies

From Theory To Practice. Depok. PT RajaGrafindo Persada. 